\title{
IMPACT AND CONSEQUENCES OF THE COVID-19 VIRUS ON THE ECONOMY OF THE UNITED STATES
}

\author{
GAVRILOVIC Kristina ${ }^{1}$, VUCEKOVIC Milos ${ }^{2}$
}

\author{
${ }^{1}$ Belgrade Banking Academy, Belgrade (SERBIA) \\ ${ }^{2}$ Singidunum University, Belgrade (SERBIA) \\ Emails: kristina.rutovic216@gmail.com; milosvu@gmail.com
}

\begin{abstract}
The crisis caused by the COVID-19 virus is not just a global health crisis. The impact of the pandemic, caused by this virus, has strongly affected almost all vital economic sectors of the United States, which has seriously affected the global economy and other financial markets around the world. Significant declining incomes at all levels, rising unemployment, and disruptions in the industrial and transportation sectors are just some of the consequences caused by this virus in the economy of the United States. As the COVID-19 pandemic continues, the United States strongly opposes further reductions in economic growth and profits with several measures taken to mitigate the effects of the virus. In that sense, proactive action by the Government of the United States is necessary to protect economic prosperity and maintain sustainable economic growth for a longer period.
\end{abstract}

Keywords: economy of the United States, COVID-19, economic consequences, unemployment

JEL: E60

UDC: 338.124.4(73)

616.98: [578.834]:338.12.015

COBISS.SR-ID 28647689

\section{Introduction}

The World Health Organization (WHO) declared the beginning of the pandemic of the COVID-19 virus in January 2020. The pandemic, caused by the COVID-19 virus, has negatively affected the global economy in all economic branches, as well as the health system around the world in recent months. It is estimated that, since the beginning of the pandemic, the world economy has lost almost 90 billion dollars, which is the biggest economic recession in the last 100 years [1]. Government around the world are trying to reconcile the goals of their economic policies and the resulting health crisis.

The US economy was the world's largest economic giant since the end of the 19th century, and during 2018, the share of the US economy in the world's gross domestic product was $25.12 \%$, while the share of China's gross domestic product was $14.9 \%$ [2]. In third place was the Indian economy with a $6.4 \%$ share in world gross domestic product. The biggest problem in the economy of the United States of America (USA), as one of the most developed economies in the world, is related to facing the budget deficit, which is directly proportional to the increase in social benefits for unemployed workers and employees who lost their jobs due to the crisis. Providing financial support to the U.S. national health system, which is under great pressure from the WHO, due to the vaccine development and testing process, is 
classified at the same time as a financial effort aimed at caring for and protecting citizens. The implementation of monetary and fiscal policy, which supports the financial markets and stock exchanges in the United States to maintain economic activity, at the same time helps companies that are under pressure from financial problems and emerging illiquidity. The implementation of fiscal policy to stimulate economic activities in the United States, with households that have limited ability to spend, determine the levels of income and the course of their economy or the so-called precautionary savings.

The intervention of the Fed (Federal Reserve) and the US monetary authorities is mainly focused on debt and US corporate bond markets to stabilize the financial market and provide liquidity. This activity calls into question the ability of the U.S. financial market to perform its core price risk functions and capital allocation.

The fiscal and monetary policies of the USA, which have been adopted so far to solve the problems with the direct impact of the economic crisis caused by the COVID-19 virus, are in direct proportion to the measures related to financial support to households, companies, state and local governments.

Policymakers and participants in the U.S. financial and commodity markets largely hope that the global economic recovery will begin in the third quarter of 2020, assuming there is no second wave of COVID-19 virus infection. Some forecasts, however, increase the likelihood that a pandemic could negatively affect global economic growth over time with a slow economic recovery [3]. Without a quick resolution to the health crisis, the economic crisis may last longer than most economic analysts have assumed. U.S. policy is expected to select the most effective combination of additional fiscal and monetary policies, which can be applied. Additional financial measures may need to balance the competing needs of households, firms, state, and local governments.

\section{The impact of the COVID-19 virus on U.S. unemployment}

At the end of June this year, a large number of US federal states demanded the reestablishment of guidelines for social distancing and the closure of certain companies, as a result of the increase in new confirmed cases of COVID-19 virus, with the possibility of delayed economic recovery. On June $29^{\text {th }}$ this year, the Federal Open Market Committee (FOMC) indicated that the increase in COVID-19 cases in the United States had a significant impact on reduced economic growth and that the path to economic recovery will depend significantly on the flow of the virus itself. The current global health crisis will greatly hamper economic activity, employment levels, and short-term inflation rates in the U.S. economy and pose significant risks to economic recovery in the medium term.

Since the beginning of the pandemic caused by the COVID-19 virus, at one point more than 80 countries closed their borders to the arrivals of U.S. citizens, keeping their residents in quarantine. During the 21 weeks, from mid-March to early August 2020, 56 million Americans applied for unemployment insurance. The number of unemployed insurance beneficiaries was 15.5 million at the beginning of August, which is the maximum of 25 million recorded in mid-May [4] [5].

The total number of people seeking unemployment benefits under unemployment insurance on July $25^{\text {th }}$ this year was 28.3 million, a record number compared to 1.7 million on the same date in 2019. The Bureau of Labor Statistics (BLS) has released data that 20 million Americans lost their jobs during April 2020, raising the U.S. national unemployment rate to $14.7 \%$, the highest unemployment rate since the Great Depression in the 1930s. Preliminary data also show that the gross domestic product (GDP) of the United States decreased by $9.5 \%$ in the second quarter of 2020 compared to the first quarter, which is the largest quarterly decline in US GDP recorded in the last 70 years [6]. 


\section{The consequences of the pandemic on the US economy}

Recognizing the growing impact of the pandemic on financial markets and economic growth, the US Federal Reserve (FED) has taken several steps to promote economic and financial stability that includes the Fed's monetary policy with its role as a provider of socalled final loan. Some of these actions are intended to stimulate economic activity, reduce interest rates, while others are intended to provide liquidity to financial markets so that companies have access to the necessary financial resources. Explaining its decisions, the Fed pointed out that "the process of eradicating the COVID-19 virus has damaged communities and disrupted their economic activities in many countries, including the United States". The first half of this year saw a 30\% drop-in economic activity or more in economic sectors such as transport, tourism, and catering, as a result of quarantine measures adopted across the country. Unlike other sectors of the economy, food and beverage consumption increased by $25 \%$, as a result of the transition of individuals who used food services in restaurants and other commercial establishments but are now preparing food at home. On August $5^{\text {th }}$, the U.S. Census Bureau reported a total monthly trade deficit of $\$ 4.1$ billion, indicating higher imports than exports of goods and services. The trade deficit in goods narrowed from $\$ 76$ billion in May to $\$ 72$ billion in June, while the trade surplus in the services sector rose from $\$ 21.4$ billion to $\$ 21.5$ billion [7].

During the month of June, exports of goods and services in the United States decreased by $15.7 \%$ compared to the period in 2019 , while imports of goods and services decreased by $14.2 \%$, due to a general decline in world trade level. Data on GDP during the second quarter of 2020 show that US trade decreased sharply in real or measured by indices in terms of the quantity of exported or imported goods and the value of those goods. The data show that the sharp decline in US trade was the result of measures taken at a global level, due to actions to prevent the spread of the COVID-19. pandemic [7].

Quantitatively, U.S. exports decreased by $25 \%$, while imports in the second quarter decreased by $15 \%$ compared to the previous quarter. In terms of value, exports decreased by $6 \%$, while imports decreased by $3.7 \%$ compared to the first quarter [8].

Table 1. Before the changes in the most important US economic sectors Source: U.S. Bureau of Statistics, Department of Economics, CRS

\begin{tabular}{|l|r|r|r|r|}
\hline Sectors & \multicolumn{1}{|l|}{$\begin{array}{l}\text { Simple } \\
\text { multiplier }\end{array}$} & \multicolumn{1}{l|}{$\begin{array}{l}\text { Starting } \\
\text { Effect }\end{array}$} & \multicolumn{1}{l|}{$\begin{array}{l}\text { Direct } \\
\text { effects }\end{array}$} & \multicolumn{1}{l|}{ effects } \\
\hline Hospitality & 1.6212 & 1.0000 & 0.3617 & 0.2595 \\
\hline Tourism & 1.3680 & 1.0000 & 0.2227 & 0.1454 \\
\hline Education & 2.4498 & 1.0000 & 0.7697 & 0.6801 \\
\hline Health Insurance & 1.5105 & 1.0000 & 0.3158 & 0.1948 \\
\hline Retail & 1.7997 & 1.0000 & 0.4440 & 0.3557 \\
\hline Public sector & 1.6728 & 1.0000 & 0.4662 & 0.2066 \\
\hline Construction & 1.4714 & 1.0000 & 0.2823 & 0.1891 \\
\hline Transport & 1.4961 & 1.0000 & 0.2987 & 0.1974 \\
\hline Storage Services & 1.8451 & 1.0000 & 0.4772 & 0.3679 \\
\hline Wholesales & 1.8296 & 1.0000 & 0.4639 & 0.3658 \\
\hline IT industry & 1.4012 & 1.0000 & 0.2339 & 0.1673 \\
\hline Banking sector & 1.1891 & 1.0000 & 0.1503 & 0.0388 \\
\hline
\end{tabular}


Table 2. After the changes in the most important US economic sectors

Source: U.S. Bureau of Statistics, Department of Economics, CRS

\begin{tabular}{|l|r|r|r|r|}
\hline Sectors & \multicolumn{1}{l|l}{$\begin{array}{l}\text { Simple } \\
\text { multiplier }\end{array}$} & \multicolumn{1}{l|}{$\begin{array}{l}\text { Starting } \\
\text { Effect }\end{array}$} & \multicolumn{1}{l|}{$\begin{array}{l}\text { Direct } \\
\text { effects }\end{array}$} & \multicolumn{2}{l|}{$\begin{array}{l}\text { Indirect } \\
\text { effects }\end{array}$} \\
\hline Hospitality & 1.3629 & 1.0000 & 0.2086 & 0.1543 \\
\hline Tourism & 1.7874 & 1.0000 & 0.4677 & 0.3197 \\
\hline Education & 2.6027 & 1.0000 & 0.6698 & 0.9328 \\
\hline $\begin{array}{l}\text { Health } \\
\text { Insurance }\end{array}$ & 1.9136 & 1.0000 & 0.4936 & 0.4200 \\
\hline Retail & 2.0978 & 1.0000 & 0.5851 & 0.5127 \\
\hline Public sector & 1.8986 & 1.0000 & 0.5046 & 0.3940 \\
\hline Construction & 1.6275 & 1.0000 & 0.3722 & 0.2553 \\
\hline Transport & 1.6446 & 1.0000 & 0.3871 & 0.2575 \\
\hline $\begin{array}{l}\text { Storage } \\
\text { Services }\end{array}$ & 1.4867 & 1.0000 & 0.2464 & 0.2403 \\
\hline Wholesales & 1.5969 & 1.0000 & 0.3498 & 0.2471 \\
\hline IT industry & 1.5496 & 1.0000 & 0.3028 & 0.2468 \\
\hline Banking sector & 1.7522 & 1.0000 & 0.4340 & 0.3182 \\
\hline
\end{tabular}

Losses caused by the decline in the employment rate affected all sectors of the economy, along with all working groups. The gradual recovery or increase in jobs is slowly becoming recognizable in the tourism and hospitality industry (especially in restaurants and cafes), educational institutions, the public sector, retail trade, consulting services, and the health care sector. During May, the U.S. Department of Labor reported that the number of unemployed increased by 20 million, not including about 10 million part-time workers and another 9 million unemployed who are actively looking for work. The number of unemployed individuals increased the most in the tourism and hospitality sector, thus reflecting the implementation of a national quarantine policy to reduce the spread of COVID-19 by reducing social contacts.

Table 3. Before the changes in the most important US economic sectors Source: U.S. Bureau of Statistics, Department for Unemployment, CRS

\begin{tabular}{|l|r|r|r|r|}
\hline Sectors & \multicolumn{1}{|l|}{$\begin{array}{l}\text { Simple } \\
\text { multiplier }\end{array}$} & $\begin{array}{l}\text { Starting } \\
\text { Effect }\end{array}$ & \multicolumn{1}{l|}{$\begin{array}{l}\text { Direct } \\
\text { effects }\end{array}$} & \multicolumn{2}{l|}{$\begin{array}{l}\text { Indirect } \\
\text { effects }\end{array}$} \\
\hline Hospitality & 1.2175 & 1 & 0.1405 & 0.077 \\
\hline Tourism & 1.6976 & 1 & 0.3918 & 0.3058 \\
\hline Education & 3.2561 & 1 & 1.4655 & 0.7906 \\
\hline Health Insurance & 1.5896 & 1 & 0.3842 & 0.2055 \\
\hline Retail & 2.3898 & 1 & 0.7799 & 0.6099 \\
\hline Public sector & 2.6481 & 1 & 0.9814 & 0.6668 \\
\hline Construction & 2.5007 & 1 & 0.7504 & 0.7503 \\
\hline Transport & 2.9296 & 1 & 1.0464 & 0.8832 \\
\hline Storage Services & 2.2292 & 1 & 0.6512 & 0.578 \\
\hline Wholesales & 2.0491 & 1 & 0.5613 & 0.4878 \\
\hline IT industry & 2.0128 & 1 & 0.5737 & 0.4392 \\
\hline Banking sector & 1.3528 & 1 & 0.2465 & 0.1062 \\
\hline
\end{tabular}


Table 4. After the changes in the most important US economic sectors Source: U.S. Bureau of Statistics, Department for Unemployment, CRS

\begin{tabular}{|l|r|r|r|r|}
\hline Sectors & \multicolumn{1}{|l|}{$\begin{array}{l}\text { Simple } \\
\text { multiplier }\end{array}$} & $\begin{array}{l}\text { Starting } \\
\text { Effect }\end{array}$ & \multicolumn{1}{l|}{$\begin{array}{l}\text { Direct } \\
\text { effects }\end{array}$} & \multicolumn{1}{l|}{$\begin{array}{l}\text { Indirect } \\
\text { effects }\end{array}$} \\
\hline Hospitality & 1.3094 & 1.0000 & 0.1780 & 0.1314 \\
\hline Tourism & 1.8688 & 1.0000 & 0.5235 & 0.3453 \\
\hline Education & 3.6662 & 1.0000 & 0.9682 & 1.6980 \\
\hline Health Insurance & 1.5365 & 1.0000 & 0.3112 & 0.2253 \\
\hline Retail & 1.6697 & 1.0000 & 0.3869 & 0.2828 \\
\hline Public sector & 1.5109 & 1.0000 & 0.3045 & 0.2065 \\
\hline Construction & 1.4245 & 1.0000 & 0.2766 & 0.1480 \\
\hline Transport & 1.6261 & 1.0000 & 0.3865 & 0.2396 \\
\hline Storage Services & 2.9651 & 1.0000 & 1.2186 & 0.7465 \\
\hline Wholesales & 1.8016 & 1.0000 & 0.4771 & 0.3245 \\
\hline IT industry & 1.3912 & 1.0000 & 0.2300 & 0.1612 \\
\hline Banking sector & 1.1972 & 1.0000 & 0.1346 & 0.0626 \\
\hline
\end{tabular}

From the previous table, the biggest disruption will be the planned realization of GDP growth, followed by the unemployment rate, which is expected to increase by the end of 2020 , if the second wave of infections caused by the COVID-19 virus occurs. Following the previous research, there is a statistically significant difference between the sectors that have suffered the greatest losses, such as tourism, catering, transport in comparison to the IT and banking sectors.

The Federal Reserve's analysis showed that nearly $40 \%$ of employees who worked in February and earned less than \$ 40,000 a year lost their jobs during March [9]. The overall response of U.S. economic policy is to provide measures to facilitate and maintain liquidity and stability, with extended support for the country's economic recovery. Research shows that prolonged recessions could leave permanent damage to the production capacity of the U.S. economy in the coming years. Long periods of unemployment can damage or end a worker's career as their skills lose value leaving their families in higher debt.

The loss of several thousand SMEs across the country would ruin the lives and work of many business leaders and communities, limiting the power of economic recovery when it comes. These companies are the main source of employment, something we will hardly need when people are trying to return to work. The prolonged recession and weak recovery may also discourage business investment and the process of further business expansion, as well as limit job reopening as well as capital growth and technology development.

\section{The impact of the COVID-19 pandemic on the value of the dollar}

All the current problems with currencies are caused by the disturbance of the balance on the world financial market, and they result from the relations between the USA and China, that is, the relations between the dollar and the yuan. When the Chinese currency, the yuan, approaches full liberalization of capital flows, it will become one of the more attractive currencies. Until that moment, a lot of time will pass because the Chinese still have significant trade and monetary barriers to the liberalization of financial flows. In addition to the substitution of the dollar by the euro in foreign exchange reserves, the substitution of the yuan can be considered in the future. Savings in Chinese yuan can be based on the following assumptions [10]:

1) in terms of total gross domestic product, China will, if it continues like this, overtake the United States in less than 20 years. 
2) China is the country with the largest foreign exchange reserves in the world and with the largest economic potential.

3 ) in the last 2000 years, China has been the largest economic power for 19 centuries, which justifies its possibility of regaining the leading economic position in the world.

The autonomy of the Chinese currency, the yuan, is extremely important and it affects economic trends in the world. In the current world economic system, the demand can also be managed by financing its surpluses. Chinese surpluses are now being used by buying US Treasury securities.

According to the medium-term forecast, US GDP is expected to decline by $6.5 \%$, the unemployment rate could rise to $9.3 \%$, and the inflation rate by only $0.8 \%$ compared to the December 2018. projections. At the end of last year, GDP growth is projected at 2.0\%, unemployment rates at $3.5 \%$, and inflation rates at $1.9 \%$. The possible reduction in GDP, however, could vary between $-4.2 \%$ and $-10.2 \%$ with a possible unemployment rate between $7.0 \%$ and $14.0 \%$ [11]. According to the FOMC, a range of estimates was necessary to present the state of the US economy in the case of the so-called "extremely high uncertainty", which is directly proportional to the economic effects of the pandemic and the reactions or measures of the US economy to past economic shocks. As a result of the significant degree of uncertainty of further economic growth and the risk of economic downturn related to the COVID-19 pandemic, the public is increasingly mentioning a pessimistic scenario that includes the time it takes for the US economy to recover and achieve economic growth. and the development it recorded at the end of 2019.

According to initial estimates, they indicate the possibility of a second wave of the COVID-19 virus in the fourth quarter of 2020, with certain restrictions on social activities and business within the US economy [12].

Table 5. SPSS analysis of changes in GDP, unemployment, and inflation Source: SPSS calculation of the author's analysis

\begin{tabular}{|l|l|l|l|l|l|l|}
\hline & Source: SPSS calculation of the author's analysis \\
Variable & $\begin{array}{l}\text { BDP } \\
\text { Change }\end{array}$ & $\begin{array}{l}\text { Projection } \\
\text { December } \\
\mathbf{2 0 1 9}\end{array}$ & $\begin{array}{l}\text { Rate of } \\
\text { unemplo } \\
\text { yment }\end{array}$ & $\begin{array}{l}\text { Projection } \\
\text { December } \\
\mathbf{2 0 1 9}\end{array}$ & $\begin{array}{l}\text { Inflati } \\
\text { on rate }\end{array}$ & $\begin{array}{l}\text { Projection } \\
\text { December } \\
\mathbf{2 0 1 9}\end{array}$ \\
\hline M & $-6,5$ & 1,8 & 9,3 & 3,5 & 0,8 & 1,9 \\
\hline Min & $-7,6$ & 2,0 & 6,5 & 3,5 & 0,6 & 1,7 \\
\hline Max & $-5,5$ & 2,3 & 14,0 & 4,1 & 1,8 & 2,2 \\
\hline Std. De. & 2,1 & 2,0 & 4,0 & 1,7 & 0,402 & 1,8 \\
\hline Var. & $-9,8$ & 1,9 & 3,7 & 2,2 & 0,170 & 2,1 \\
\hline
\end{tabular}

Comparing parameters such as the change in GDP, the unemployment rate, and the inflation rate at the end of the second quarter (June 2020) in relation to the projected value at the end of 2019, it can be noticed that they significantly deviate from the planned ones. The impact of the pandemic caused by the COVID-19 virus on the US economy has significantly disrupted their projected values.

The basic measures that the world's most developed countries are taking to address the global economic crisis and accelerate development, but sustainable are the establishment of confidence, growth and jobs recovery of the financial system to enable re-lending strengthening financial regulation to restore confidence establishment and reform of international financial institutions to overcome the crisis and prevent a future crisis by promoting global investment trade and rejecting protectionism, and fostering prosperity work for an inclusive, environmentally friendly and sustainable recovery. In order for such measures to be implemented, it is necessary to implement certain macroeconomic measures in 
the world economy through fiscal policy, monetary policy, and enabling a sustainable economy [13].

All these measures and all actions must be coordinated between the governments of the states, then their financial institutions and organizations, as well as the international financial institutions. Within this, measures should be taken to establish sound financial audit and regulation. The lack of these measures is one of the main reasons for the global financial crisis. The decline in global demand, which was first recorded after 25 years, is a consequence of growing protectionist pressure as well as the withdrawal of commercial loans. Measures to revive world trade include removing barriers to investment or international trade in goods and services and stimulating exports, enabling the free movement of capital internationally, increasing the role of the World Trade Organization and greater involvement of developing countries in international trade.

The global economic crisis has enabled the most developed countries, such as the G-20, to face the social implications of the crisis, because it affects the poorest countries the most.

Social protection measures in these countries must start primarily from long-term investments that will enable them security of food supply, primarily through donations from the most developed countries through the World Bank [14]. To achieve economic development, and above all the growth of sustainable technology, financial sources are needed. In this way, the economy should be protected, and the overall growth of the world economy should be ensured.

The additional financial resources needed for the recovery of the world economy should be generated through the International Monetary Fund and multilaterally developed banks that would support development, and it is estimated that an additional 850 billion dollars are needed for these activities.

It is also a very important way of distributing these funds, where $\$ 250$ billion should be set aside in bilateral measures through bilateral financing of IMF members, and then a new way of borrowing from the IMF should be expanded and made much more flexible. One of the measures is to increase the IMF's lending capacity by its founders to meet the needs of low-income countries as much as possible and to provide additional limits for special drawing rights were the equivalent of $\$ 250$ billion is planned to increase global liquidity. Of that amount, \$ 100 billion should be invested directly to improve market conditions and economic development. It is necessary to direct all these resources and opportunities to increase the capacity of international financial institutions to better respond to the economic crisis [15].

Developing countries, as well as the poorest ones, need to be better represented and more concretely seen in these institutions. Significant resources from monetary funds should be invested in meeting the large global demand for electricity and transport, so that energy needs are met by renewable sources (solar energy, biomass fuel, wind, etc.). The negative consequence of energy demand is further planning for the use of nuclear energy sources.

\section{Macroeconomic conditions in the world during the crisis caused by the COVID-19 pandemic}

The world economic crisis, which spread to the whole world at the speed of light, taking its toll both in developed countries and countries in transition, and thanks to the process of world globalization, managed to remove numerous economic and non-economic barriers. At the very beginning of the globalization process, it was believed that the developed ones would achieve a larger amount of savings from investments and by placing them through direct investments and foreign direct involvement in developing countries. Guided by this opinion, it was considered that developed countries would achieve a high level of surplus within the current part of the budged balance during the process of globalization. The initial assumptions 
for this claim were based on parameters such as a higher level of product quality, a wide range of products, and cheap labor in the so-called countries of the third world.

Developing countries are characterized by low wages and access to technologies that, thanks to the transfer of know-how, provide favorable opportunities for high investment rates.

Developing countries had the opportunity and the prospect of achieving high rates of economic growth due to low personal incomes, the impossibility of aging the high rate of savings deposits, and as a consequence of such economic opportunities and the realization of a high balance of payments deficit. The current account deficit was particularly pronounced in the area related to its current part. Although no one expected such a course of events, the causes of such developments in the international financial market are due to a greater propensity to save due to uncertain economic policies and inadequate living conditions that are characteristic of these Asian countries. In the same period, OPEC farmers sold their financial surpluses, which they earned from the export of oil and oil derivatives, through investment funds.

Observed from an Asian country's point of view, low personal incomes, and technology transfer from developed countries did not give the expected results for a higher level of investment due to the uncertainty of property rights. Another argument in favor of developing countries is the tendency to resist (aversion) to the possibilities of risk and the willingness to invest in more lucrative and legally secure businesses with lower returns. This reason was the key reason why banks and other financial institutions from developing countries decided to invest in the US market, which was considered to be less exposed to risk. The lower level of risk-taking by the United States has found its foothold in the view that the United States has a high degree of liquidity and investment security [16].

The tax rate in times of recession should not discourage investors from investing their money, and a policy that advocates a higher level of tax than the current one is unacceptable.

Lower tax rates mean more money to spend and thus accelerate the recovery of the economy. This attitude had, so far, a mostly positive effect on the wealthy U.S. population.

The reform of the financial system requires the separation of commercial banking from investment banking. The biggest changes in theory brought about by the current crisis are related to the regulation of the financial sector, the change in attitudes towards inflation, the place, and the role of central banks. The reform of the financial system is also based on models that advocate proposals to cover the shown losses in the future with the funds of shareholders instead of taxpayers.

\section{Conclusion}

The world economic crisis, whose beginnings date back to December 2019, is not ordinary but is one of the phenomena that can only be compared to the crisis of 1929. The global financial crisis, caused by the COVID-19 pandemic, is still ongoing, and its final consequences will be seen only in the years to come.

Today's achievement of scientific-technological, economic, and social development level has enabled companies to license their technology, jointly invest capital, create alliances in "third world" countries where their organizational and production units are already located, etc. All these facts have contributed to the process of globalization, which has contributed to the global economic crisis largely prevailing in all countries of the world in a relatively short time. In that way, the internationalization of capital took place, that is, the placement of capital on an international scale. The aspiration of large monopolies to make as much monopoly extra profit as possible on the one hand and cheap raw materials and labor on the other contributed to the creation of international monopolies whose capital eroded during the ongoing global financial crisis. 
The real depth of the global financial crisis is hidden by numerous government interventions and the effects of the crisis are more realistically on the side of unemployment than it was reflected in the decline in gross domestic product. The losses caused by the crisis are huge and are reflected in a large drop in the gross domestic product, in the enormous growth of public debts, and in the monetary expansion that was accompanied by uncontrolled printing of money. The clearer impact of the global financial crisis is visible through the increased current deficit account and external debt than it was reflected through the level of the budget deficit and the amount of public debt. As a result, the economies of countries around the world have been misled that only by controlling public spending can a crisis be avoided while ignoring borrowing from the private sector.

\section{REFERENCES}

[1] Newsrelease, Eurostat, 2020.

[2] C. Office, "Quarterly Estimates of GDP for April-June 2020 (First Preliminary Estimates)", 2020.

[3] J. H. Powell, "Coronavirus and CARES Act, Testimony before the Committee on Banking, Housing and Urban Affairs", U.S. Senate, 2020.

[4] D. o. Labor, "Unemployment Insurance Weekly Claims," [Online]. Available: https://www.dol.gov/. [Accessed 138 2020].

[5] T. Roman and J. Stein, "2.4 Million Americans Filed Jobless Claims Last Week, Bringing Nine Week Total to 38.6 Million," The Washington Post, 2020.

[6] B. o. L. Statistics, "The Employment Situation-April 2020," 2020.

[7] B. o. E. Analysis, "Gross Domestic Product, $2^{\text {nd }}$ Quarter 2020 (Advance Estimate) and Annual Update," 2020.

[8] G. Chanzan and A. Gross, "Europe Battles to Contain Surge in Coronavirus Cases," Financial Times, 2020.

[9] B. o. L. Statistics, "The Employment Situation-May 2020,” 2020.

[10] B. f. I. Settlements, “Annual Economic Report 2020,” 2020.

[11] E. Commission, "European Economic Forecast Summer 2020," 2020.

[12] I. M. Fund, "World Economic Outlook Update," 2020.

[13] J. Wheatley, T. Stubbington, M. Stott, A. England and C. Cotterill, "Debt Relief: Which Countries Are Most Vulnerable?" Financial Times, 2020.

[14] G20, "COVID-19 Pandemic: Financial Stability Implications and Policy Measures Taken,” 2020.

[15] B. o. G. o. t. F. R. System, "Federal Reserve Issues FOMC Statement” 2020.

[16] n. M. Fund, "World Economic Outlook Update," 2020.

\section{Article history:}

Received 4 November 2020

Accepted 10 December 2020 